\title{
Hvordan kan man best nå ut til både motiverte og umotiverte studenter på grunnkurs i kjemi?
}

\author{
Simen Antonsen, ${ }^{*}$ Dorentina Osmani,* Anne Gravdahl,* Helge Ørjan K. Stenstrøm,* \\ Marius Samuelsen, ${ }^{\#}$ Yngve Stenstrøm* \\ *Norge Miljø- og Biovitenskapelige Universitet (NMBU), KBM, Postboks 5003, $N 1433$ As \\ ${ }^{\#}$ Norge Miljø- og Biovitenskapelige Universitet (NMBU), Loeringssenteret, Postboks 5003, N 1433 As
}

\begin{abstract}
Mange studieretninger har grunnkurs i fag som ikke er hovedstudieretningen for programmet. Dette gjelder fag som matematikk, fysikk og kjemi. Erfaringsmessig er det vanskelig å motivere studenter i disse fagene som for mange kun blir stottefag. Samtidig kan man ikke forenkle studiet for mye siden det også skal danne grunnlag for de som skal gå videre til en mastergrad eller doktorgrad i faget. Vi har sett på muligheter for at studenten selv skal kunne få mange tilbud og selv kunne bestemme hvilke av disse tilbudene som passer best for den enkelte. Prosjektet ser spesielt på tilrettelegging innen kjemifaget, spesifikt innenfor grunnleggende organisk kjemi. Vi har konsentrert oss om innforing av en del digitale hjelpemidler hvor forskjellige spørsmålsdatabaser og (enkle) spill har vært elementer. Den enkle hypotesen er at alle studenter er ulike og at det som passer for én ikke nodvendigvis passer for en annen. F.eks. at noen synes at "gammeldagse» forelesninger er bra, mens andre ikke har læringsutbytte fra dette i det hele tatt. Tanken er at man inkluderer flere alternative læringsporter/læringsmetoder som gjør at studenten selv kan velge det som passer best for den enkelte. Dette legges ut digitalt slik at studenten selv kan velge det som er mest motiverende for den enkelte. I tillegg bør så mye av dette som mulig være robust nok til at ikke alt må forandres selv om man bytter lærebok. Prosjektet startet for flere år siden og har de siste 2 årene hatt stotte fra DIKU.
\end{abstract}

\section{INTRODUKSJON:}

I mange studieprogrammer er det utfordrende at man har store basiskurs i generelle fag som for eksempel STEM-fagene. Dette favner både studenter som skal studere disse fagene og studenter som bare skal ha kursene som støttefag for studier som går i helt andre retninger. Spesielt for sistnevnte gruppe er det ofte vanskelig å motivere studentene. Dette har mange uheldige sider. Et aspekt er at mange av disse studentene stryker og dermed tar opp unødig plass samtidig som de blir forsinket i studieløpet og i verste fall også avbryter studiet. Et annet aspekt er at for studenter med lite motivasjon vil detaljer fra faget bli fort glemt fremfor å danne bakgrunn for det reelle studiet. Blant andre Osborne og Collins påpeker viktigheten av at vi ikke utelukkende utdanner forskere, men også vanlige borgere med innsikt nok innen vitenskap til å fatte demokratiske beslutninger.[1,2]

Vi har sett på dette gjennom flere år og konsentrert oss spesielt om kurs i organisk kjemi, men med ønske og håp om at kunnskap her skal kunne overføres til andre kjemi-kurs og kanskje også til andre fagdisipliner.

Mange mener at man skal innføre nye metoder for læring, mens tradisjonell undervisning med forelesninger er ofte ses på som mindre læringsfremmende.[3,4] Eksempelvis skriver professor Mariappan Jawaharlal følgende: "A traditional lecture is like a one-way street: students are passive listeners, the information flows from the teacher to the students, and it is not easy to tell whether the learner has absorbed the material."'[5] Snakker man imidlertid med studentene viser det seg at mange kan ha motforestillinger mot nevnte undervisningsmetode, men overraskende mange er også positive. For eksempel er det overraskende mange som kommer på tradisjonelle forelesninger selv om disse filmes og opptak legges ut på nettet og/eller andre alternativer tilbys. Forskningen viser at de som deltar i forelesningen, i snitt får bedre karakter på eksamen enn de som ikke deltar.[6] Dette trenger likevel ikke være direkte relatert til hvorvidt studentene faktisk deltar i forelesning eller ikke, men kan like gjerne være avhengig av hvilken persontype de er. Vi vet fra en rekke studier at:

1. Noen studenter er innadvendte, mens andre er utadvendte

2. Noen liker å samarbeide, mens andre liker å jobbe alene 
3. Noen er svært kreative, mens andre ikke er det

4. Noen liker å sitte stille, mens andre ikke klarer det

Kort sagt: Alle studenter er forskjellige.[7-9] Vår hypotese er da at: "Studentene lærer best ved at de kan velge fra flere verktøy hva som gir best læringsutbytte. Ingenting passer for alle". Vi ønsker derfor å tilby en rekke undervisningstilbud for å nå ut til så mange som mulig. Albert Bandura skrev at «a strong sense of efficacy enhances human accomplishment and personal well-being in many ways. People with high assurance in their capabilities approach difficult tasks as challenges to be mastered rather than as threats to be avoided», som kort beskriver hva vi ønsker å oppnå - et undervisningstilbud der mestring og trivsel fører til læring.[10]

I henhold til Piaget vil enhver student konstruere sin forståelse gjennom en konstruktiv prossess. Ved å bruke aktuelle nyhetssaker (for eksempel om klimakrise) til mer hverdagslige møter med kjemi har vi forsøkt å illustrere for studentene at kjemien angår dem, samt at teorien kan bygges inn i forståelsen de allerede har av verden gjennom hverdagslige opplevelser og nyheter presentert i media. Selv om mange verktøy gjøres tilgjengelig er det noen skjær i sjøen som må tas med. En selvsagt fare er at overambisiøse studenter prøver å ta alle verktøy i bruk. Det er også fare for at studentene ikke finner de forskjellige verktøyene som passer den enkelte best. Det er derfor viktig med informasjon og klar veiledning om alternativene de har tilgjengelig. Det er også sannsynlig at for en enkelt student kan et verktøy passe best for et tema, mens et annet verktøy er bedre for et annet. Derfor er det viktig at de enkelte verktøyene er klart definerte, lett å finne frem til og kan presenteres for studentene på et tidlig tidspunkt $\mathrm{i}$ kurset, gjerne helt ved starten.

\section{RESULTATER OG DISKUSJON:}

Opprinnelig var kurset bygd opp tradisjonelt med forelesninger, kollokvier og laboratoriekurs. Underveis har dette blitt utviklet mot å gjøre det mer sammensatt. Dette har fulgt innføringen av digitale hjelpemidler og verktøy.

Vi har i mange år benyttet en langsgående vurdering. Vi har to deleksamener i løpet av semesteret før slutteksamen. I tillegg teller laboratoriekurset med i vurderingen. Det er i laboratoriekurset et opplegg med en læringssti og påfølgende test som på fullføres i Canvas før studentene får lov til å utføre de praktiske laboratorieoppgavene. Deretter skal det skrives en rapport som må godkjennes før de får ta eksamen.

Siden dette er et kurs med $>100$ studenter kan ikke tidspunkt for eksamener og laboratorieøvelser tilpasses den enkelte, men vi ønsker å legge opp til stor frihet utenom dette. Disse bolkene har vært viktig da mye av kursets senere elementer krever forståelse av de tidligere for å gi noe læringsutbytte, noe som er beskrevet av blant annet Rodríguez og medarbeidere har sett på hvordan manglende teoretisk bakgrunn innen kjemi hindrer studentene i å kunne forstå nye konsepter.[11]

Om temaet skrev Herron følgende: «Before one can reason with hypotheses and deductions based on experience, there must be a sound descriptive base which has been put in order».[12] Spesielt interessant er dette for laboratorieundervisning. Beistel konkluderte med at forståelse for bakgrunn er nødvendig for at studenten skal forstå eksperimentene. Herron viser til hvordan en student som har kommet til et akseptabelt nivå vil se variabler i et eksperiment, mens lavere nivå ikke vil forstå dette som mer enn en "kokebokoppskrift". [12,13]

Vi vet at de ulike personlighetstypene har ulike forutsetninger til å lykkes. Sett fra et Vygotskijs teorier om den proksimale utviklingssonen, vil studentene trenge ulik mengde oppfølging og tilrettelegging. Vi ønsker da å legge til rette slik at studenten kan ta utfordringene i sitt eget tempo med de verktøyene de selv ønsker å benytte. Vi har tilgjengeliggjort en rekke digitale og interaktive oppgaver, slik at flest mulig av studentene skal føle at det er en tilpasset vei for å nå målet også for dem.

Etter samtaler med studenter og gjennomgang av eksamensresultater ønsket vi å forbedre studentlæringen ved flere punkter i kurset. Målet var å ha følgende læringsmetoder med i kurset:

1. Forelesninger med strømming og opptak som gjøres tilgjengelig på nett 
2. Korte videoer med temaer som erfaringsmessig er vanskelig for studentene

3. Kollokvie- og eksamensoppgaver med besvarelser (ikke bare fasit)

4. Laboratorieundervisning med videodemoer

5. Godkjent inngangsbillett for å starte lab-øvelse (for å sikre at studentene er godt forberedt)

6. Flervalgstester og andre typer spørsmål som sortering, trykk på figurer etc.

7. Enkel type spill

Kommentarer til de enkelte punktene:

1. Tradisjonelle forelesninger strømmes i sann-tid og legges ut på nettet (Canvas) rett etter forelesning. Det er muligheter for redigering og tilpasning. Studentene kan se på enkeltdeler av forelesningene. Vi har fătt mange tilbakemeldinger fra studenter som setter pris på at de da kan repetere enkeltelementer av forelesningene.

2. Fra eksamensbesvarelser og på direkte spørsmål ser man at noen temaer er spesielt vanskelige for studentene. Disse kan man da legge ut som små, innspilte videoer vanligvis på maksimum 10 minutter. Foreløpig er ca. 10 videoer spilt inn, men vi planlegger ca. 30-40 totalt. Det er en forutsetning at temaene er smale slik at man lett kan sette entydige overskrift på disse og dermed gjøre de lett søkbare. Eksempler på temaer vi har spilt inn er:

a. Grunnleggende nomenklatur

b. Nomenklatur på den enkelte stoffklasse

c. Grunnleggende stereokjemi

3. Kollokvie- og eksamensoppgaver. Spesielt for eksamensoppgavene legges det ut eksempelbesvarelser slik at studenten blir vant til hvor mye som er nødvendig for å ha besvart alt. Mange studenter vil ofte svare for kort eller for langt og trenger veiledning for dette.

4. Laboratorieundervisningen skal gjenspeile de viktigste reaksjonene i kurset. Både av sikkerhetsmessige, økonomiske og tidsmessige grunner er det begrenset hvor mange øvelser man fysisk kan gjøre. Men man må tenke nøye igjennom hva som egner seg for slike ferdig innspilte videoer.

5. For å få tilgang til laboratoriene må studentene svare på 6 spørsmål og ha rett på 5 eller 6 av disse for å få lov til å ta laboratorieøvelsen. Dette er både for å sikre at studenten vet hva de skal gjøre på øvelsen, for det rent sikkerhetsmessige og for å oppnå best mulig læringsutbytte. Spørsmålene er mest hensiktsmessig å presentere som flervalgsspørsmål, men andre formater kan også benyttes. Vi har også lagd spørsmålsbaser med flere enn 6 spørsmål, slik at studenten ikke nødvendigvis får 6 identiske spørsmål dersom de må ta testen flere ganger.

6. Til enkelte temaer er det viktig med gode spørsmål. Det bør også være flere varianter av disse. Vi har lagt ut i størrelsesorden 20-50 spørsmål innenfor hver kategori. Disse har 4 eller 5 svaralternativer.

7. Et enkelt spill er under utvikling. Her er det meningen at man kan velge rollefigur og at man så går rundt i et miljø som gjør det naturlig å svare på spørsmål. For organisk kjemi er det å sette dette inn i en litt morsom kontekst med hva såpen man bruker for dusjing inneholder, hva kaffe inneholder, hva som skal til for at noe skal brenne etc. For dette er det mer utfordrende å sette sammen spillet slik at man kan tilpasse det til hvor man er i pensum og samtidig ha en rimelig progresjon.

For at studentene skal få føle at de er i førersetet av undervisningen opprettet vi et tilbakemeldingssystem der alle kan skrive anonyme tilbakemeldinger om hva som er bra og hva som ikke er så bra. Studentene meldte aktivt inn både ris og ros. Vi var veldig nøye med å følge opp dette gjennom hele kurset, slik at studentene forsto at vi lyttet til dem.

Det ble bestemt at alt av endringer i kurset skulle organiseres i Canvas, læringsplattformen vi benytter, for at informasjonen og mulighetene skulle være tilgjengelig fra ett sted.

Alle forelesninger blir strømmet via vår læringsplattform. Totalt deltar flertallet av studenter i forelesningene enten ved fysisk oppmøte eller ved at de ser strømmede forelesninger.

Tilbakemeldingene fra studentene er også at de verdsetter forelesningene. Vi benytter en rekke avbrekk fra PowerPoint-undervisningen for å holde konsentrasjonen oppe. Disse inkluderer blant annet gjennomføring av forsøk foran klassen, "historiefortelling" og oppgavegjennomgang for å illustrere pensumet. Vi har også laget kortere, mer redigerte videoer for å illustrere viktige temaer. Det 
er også skrevet et kompendium med en mer oppgaveorientert gjennomgang av enkelte temaer som studentene opplevde som svært teoretisk tunge.

Mange av studentene meldte at de liker å følge undervisningen hjemmefra, og vi forsøkte da å ta dette med oss i kollokvieundervisningen også. Oppgavegjennomganger ble filmet og det ble også prøvd ut bruk av nettbrett med tegnesoftware for å vise oppgaveløsning via Zoom. Noe overraskende var ikke dette særlig populært og vi endte til slutt opp med en klassisk kollokvieundervisning som også ble strømmet via læringsplattformen.

For at studentene skulle få trening i oppgaver, samt sjekket hvilket nivå de lå på, opprettet vi i Canvas flere spørsmålsbanker med en rekke spørsmål innen de ulike temaene som undervises. Disse oppgavene varierer fra flervalgsoppgaver, oppgaver der ulike svaralternativer skal rangeres, "match"spill og spørsmål der man skal trykke på riktig svar i et bilde eller et skjema. Disse testene er valgfrie og teller ikke på endelig karakter.

Alle testene kan tas om igjen så mange ganger studentene vil. Hver gang vil rekkefølgen på spørsmålene og alternativene endres for å gi et høyt læringsutbytte også ved gjentagende forsøk. Studentene vil få avslørt antall riktige, og også hva som er riktig svar på spørsmålene de har besvart feil, straks de er ferdig. At vi har benyttet ulike typer oppgaver er nok en gang fordi vi ønsker at det skal være noe som passer for alle.

Dette ble godt mottatt av studentene. Mange nevnte i evalueringene at dette var til stor hjelp.

Under undervisningsperioden har det vært utfordringer med fysisk oppmøte grunnet utbrudd av korona viruset. Det har derfor vært nødvendig å utvide antall laboratoriepartier for å kunne sikre tilsvarende eller bedre læringsutbytte for ferdighetstrening på laboratoriet, samtidig som smittevernrestriksjoner og andre forbehold blir tatt hensyn til. Noen av kriteriene for å kunne drive med fysisk oppmøte under kurs, har blant annet vært å senke risiko for smittespredning. Dette ble tatt hensyn til ved å; (i) øke kapasitet på hvert kurs ved å øke antall partier; (ii) studentene arbeidet individuelt med oppgaver de tidligere har samarbeidet på; (iii) kompensasjon tidsmessig for noen individuelle arbeidsoppgaver ved å filme deler av forsøkene som ikke medfører at studentene lærer nye metoder. Kapasiteten på laboratoriekursene ble økt fra 4 partier i uka med opp mot 24 studenter i hver gruppe, til 10 partier i uka med maks 11 studenter i hver gruppe. I tillegg ble kurset utvidet med to uker for å kompensere for at to timer ble trukket fra 4 kursdager, for å få kabalen med stab til å gå opp. Det har tidligere vært krav om at to og to studenter samarbeider, men har denne høsten ikke vært et alternativ. Små forsøk som innebar at studentene ikke lærte nye metoder eller laboratorieteknikker ble filmet og videoene erstattet fysiske laboratorieforsøk. I filmene ble forsøkene introdusert med en gjennomgang av arbeidsoppgaver, før selve forsøket ble filmet og forklart underveis. Studentene fikk se på videoen så mange ganger de ønsket hjemmefra og skrev rapport også på grunnlag av resultatene fra disse forsøkene. Dette er nylig vist at forberedelsesvideoer har positiv innvirkning på prestasjon da praktisk arbeid utføres.[14]

Konsekvensene av at studentene har gjennomført alle laboratorieøvelsene uten partner har vært at de ble selvstendige både i det fysiske arbeidet på laboratoriet og med det teoretiske med rapportskriving. Flere av tilbakemeldingene fra studenter lyder slik «Synes det har vært veldig lærerikt å jobbe på egenhånd, $\mathrm{i}$ forhold til å jobbe sammen med en labpartner. Det har tvunget oss til å stå på egne bein». Opplevelsen har vært at det er høyere takhøyde for studentene å stille spørsmål da det er flere undervisere på færre antall studenter, og dermed mer tid på å undervise og skape engasjement.

På laboratoriekurset har det tidligere vært opplevd at flere studenter kommer uforberedt ved kursstart, som igjen førte til dårligere læringsutbytte. Det ble derfor etablert en ordning der studentene måtte besvare en rekke spørsmål relatert til hver enkelt laboratoriekurs før oppmøte. Spørsmålene er ikke avhengig av det fysiske arbeidet på lab slik at de enkelt kan besvares på forhånd, og er brukt som et verktøy for å forplikte studentene til å drive med forberedende arbeid. Vi har opplevd at studentene har mer oversikt over arbeidsoppgavene de skal fullføre og forstår teorien bak øvelsene..

Med tildelte DIKU-midler blir det utviklet et enkelt spill som skal motivere studenter. Spillet skal basere seg mye på humor, men også vise på en tydelig måte at kjemien er overalt rundt oss $\mathrm{i}$ hverdagen. Ved å svare feil skal de få hint om hva som er riktig svar. Ved rett svar kan de gå videre, men samtidig få lenker til utdypende forklaringer om de ønsker det. Målet med dette tiltaket er at vi 
skal nå studentene som i utgangspunktet ikke forstår relevansen med kjemi. Forhåpentligvis vil kjemi oppleves som litt mindre skremmende når de opplever en viss gjenkjennelse ved senere skal lære seg detaljene. Dette spillet har ikke blitt publisert for studentene på nåværende tidspunkt, og resultater vil rapporteres senere.

\section{KONKLUSJON:}

Flere tiltak har blitt gjort for å nå ut til flere av studentene. Et stort antall trengingsoppgaver blir tilbudt via læringsplattformen. Dette ble verdsatt av studentene og skal tas med videre, samt utvides i fremtiden. Forsøk på å modernisere forelesningene har blitt gjort ved å lage en rekke kortere videoer. Disse har også blitt godt mottatt av studentene som da får en mulighet for muntlig repetisjon av vanskelige temaer. Alle tilbakemeldinger fra studenter har vært positive til det meste av forandringene. Eksamensresultatene har blitt betydelig forbedret med mye lavere strykprosent. Det skal imidlertid sies at dette kan være påvirket av hjemmeeksamen vs. eksamen på campus.

\section{ANERKJENNELSE OG TAKK:}

En stor takk rettes til Hanne Devle, Salima, Fjeld og Lene Ruud ved NMBU, KBM for hjelp til filming av videoer. Takk også til Håkon Sverdvik ved NMBU, Læringssenteret for administrativt arbeid. Til sist en stor takk til DIKU for finansiering gjennom prosjekt DIG-prosjekt P19/2019 - Aktiv bruk av digitale metoder i kjemiundervisningen.

\section{REFERANSER:}

1. Osborne, J.; Collins, S. Pupils' views of the role and value of the science curriculum: A focusgroup study. International Journal of Science Education 2001, 23, 441-467, doi: 10.1080/09500690010006518.

2. Hurd, P.D. Scientific literacy: New minds for a changing world. Science Education 1998, 82, 407-416, doi: $\quad$ https://doi.org/10.1002/(SICI)1098-237X(199806)82:3<407::AIDSCE6 $>3.0 . C O ; 2-G$.

3. Paul, R.; Binker, A.J.A.; Sonoma State, U.; Center for Critical, T.; Moral, C. Critical thinking : what every person needs to survive in a rapidly changing world; Center for Critical Thinking and Moral Critique, Sonoma State University: Rohnert Park, CA, 1995. 0944583091 9780944583098

4. $\quad$ Bligh, D.A. What's the Use of Lectures?; Intellect books: 1998. 187151679X

5. Jawaharlal, M. Is Lecturing Bad? Availabe online: Article: https://www.huffingtonpost.com/drmariappan-jawaharlal/is-lecturing-bad b 11300278.html?ncid=engmodushpmg00000006 (accessed on

6. van Berkel, H.; Schmidt, H. On the additional value of lectures in a problem-based curriculum. Educ Health (Abingdon) 2005, 18, 45-61, doi: 10.1080/13576280500042648.

7. Sæbø, S.; Almøy, T.; Brovold, H. Does academia disfavor contextual and extraverted students? Uniped 2015, 38, 274-283, doi:

8. Vinje, H.; Almøy, T.; Brovold, H.; Sæbø, S. Adaptive statistical education to motivate and enable a growing and increasingly diverse student population Proceedings of the Satellite conference of the International Association for Statistical Education (IASE) 2019, doi:

9. Goldberg, L.R. Language and individual differences: The search for universals in personality lexicons. Review of personality and social psychology 1981, 2, 141-165, doi:

10. Bandura, A. Self-efficacy : the exercise of control; 1997. 07167262629780716726265 07167285089780716728504

11. Betancourt-Pérez, R.; Olivera, L.J.; Rodríguez, J.E. Assessment of Organic Chemistry Students' Knowledge of Resonance-Related Structures. Journal of Chemical Education 2010, 87, $547-$ 551, doi: 10.1021/ed800163g.

12. Herron, J.D. Piaget for chemists. Explaining what "good" students cannot understand. Journal of Chemical Education 1975, 52, 146, doi: 10.1021/ed052p146.

13. Beistel, D.W. A Piagetian approach to general chemistry. Journal of Chemical Education 1975, 52, 151, doi: 10.1021/ed052p151. 
14. Stieff, M.; Werner, S.M.; Fink, B.; Meador, D. Online Prelaboratory Videos Improve Student Performance in the General Chemistry Laboratory. Journal of Chemical Education 2018, 95, 1260-1266, doi: 10.1021/acs.jchemed.8b00109. 